\title{
The Influence of the Implementation of Total Quality Management and the Implementation of Good Governance on the Muzakki Trust (Study on Amil Zakat Institution in Batam City)
}

\author{
Cahyo Budi Santoso \\ Universitas Riau Kepulauan - Batam \\ Ahmad Gamal \\ Universitas WR Supratman - Surabaya \\ Paper to be presented at International Conference of Zakat 2019 \\ 3-4 October, Universitas Padjadjaran, Bandung, Indonesia
}

\begin{abstract}
Zakat becomes part of the obligations of Muslims who must be paid and given to those who are entitled to receive zakat. The distribution of zakat which is intended for the recipient and the amount of zakat is often not recorded accurately. There is a discrepancy between the amount of zakat and the number of recipients of zakat. Then a new breakthrough is needed through the implementation of toral quality management and the application of good governance so that it is expected that all incoming zakat and the number of recipients of zakat can be recorded.

This study aims to examine the effect of the implementation of total quality management and the role of good governance on muzakki trust (a study at the Amil Zakat Institute in Batam City). The population in this study is the number of residents of the city of Batam in 2017 amounted to 1,062,250 inhabitants. Determination of the sample using the formula Hair, et al (2010) so that the total sample is 100 respondents. Data analysis using multiple linear regression with SPSS 23.

The results of the study can be concluded that the implementation of total quality management has a significant positive effect on muzakki trust, the application of good governance has a significant negative effect on muzakki trust and the implementation of total quality management and the application of good governance simultaneously has a significant positive effect on muzakki trust.
\end{abstract}

Keywords: total quality management, the role of good governance and muzakki trust

\section{INTRODUCTION}

Zakat is a potential in dealing with problems, especially poverty. The country of Indonesia, which has the largest number of Muslim population, has the potential to explore the amount of zakat. Regulations or regulations have been rolled out by the Government with the aim of being able to raise zakat funds as one of the potential to overcome the existing poverty. Various regulations have been made such as Law No.23 of 2011 concerning
Management of Zakat (UUPZ), zakat management in Indonesia is entering a new phase and showing increasingly encouraging developments.

Referring to Law No. 23 indicates the involvement of the government to manage zakat. In Article 5 paragraph 1 UUPZ management of zakat becomes the authority of the government in this case the National Amil Zakat Agency (BAZNAS). And the role of the community in managing zakat is only in the context of \"assisting the taskl" of 
BAZNAS. This role can be realized through the establishment of the Amil Zakat Institute (LAZ) (article 17).

One model that can be applied to support efforts to achieve the potential of zakat in Indonesia is to implement the Total Quality Management (TQM) model. TQM is a management model in running a business to realize good governance through continuous improvement of its products, services, people, processes and environment. The implementation of the TQM model is expected to create good zakat fund. TQM needs to be applied in the management of zakat by LAZ with the aim of (1) to be able to improve competitiveness and excel in competition, (2) produce the best LAZ output, (3) increase muzaki trust, and (4) improve the quality of zakat fund management (good governance) so as to increase consumer satisfaction (Samdin, 2002 19).

In addition, it is necessary to implement good governance to support the achievement of zakat revenue targets nationally. The implementation of good corporate governance Good Corporate Governance (GCG) is a must and important foundation for the success in realizing the vision and mission and the company's business continuity. The current implementation of GCG is not only as a fulfillment of obligations, but has become a necessity in carrying out business activities of the company in order to maintain sustainable business growth, increase company value and as an effort to keep the company in competition. There are five GCG principles that can be used as guidelines for business people, namely: Transparency, Accountability, Responsibility, Independence and Fairness.

Referring to efforts to increase the receipt of zakat, it is necessary to make a tool to support through the existence of the Amil Zakat Institute (LAZ) which has received a recommendation from BAZNAS as LAZ on a national scale up to March 2016 by 11 units, thus the total number of Zakat Management Organizations (OPZ) in Indonesia can be seen in the following table.

Table 1. Number of Zakat Management Organizations in Indonesia

\begin{tabular}{clcl}
\hline No & \multicolumn{1}{c}{ Jenis OPZ } & $\begin{array}{c}\text { Amount } \\
\text { (Units) }\end{array}$ & \multicolumn{1}{c}{ Resources } \\
\hline $\mathbf{1}$ & BAZNAS Center & 1 & Kepres RI No.8 Year 2001 \\
\hline $\mathbf{2}$ & BAZNAS Province & 33 & KMA RI No. 118 Year 2014 \\
\hline $\mathbf{3}$ & BAZNAS Regency / City & 476 & Kep Dirjen Bimas No.DJ.H/37 Year 2015 \\
\hline $\mathbf{4}$ & LAZ on a national scale & 35 & www.baznas.go.id \\
\hline & Total & 545 & \\
\hline
\end{tabular}

The large number of OPZ (545 units), plus the more complete regulation will have a positive impact and give hope that zakat management in Indonesia is getting better and increasingly realizing its vision of making the ummah prosper.

Table 2. Realization of Acceptance of Alms Zakat Funds in Indonesia 2011-2015

\begin{tabular}{ccc}
\hline No. & Year & Amount (Rp Miliar) \\
\hline 1. & 2011 & 1.729 \\
\hline 2. & 2012 & 2.200 \\
\hline
\end{tabular}




\begin{tabular}{ccc}
\hline No. & Year & Amount (Rp Miliar) \\
\hline 3. & 2013 & 2.700 \\
\hline 4. & 2014 & 3.300 \\
\hline 5. & 2015 & 3.700 \\
\hline
\end{tabular}

Sources: Indonesia Zakat Outlook 2017

Based on the above data it can be interpreted that the potential is so great according to the findings of BAZNAS and IPB in 2011, data obtained from the potential for zakat in Indonesia is Rp 217 Trillion per year (Machrus, et al, 2013). But the realization is only $0.78 \%$ to $3.77 \%$ or only $1.7 \%$ has been realized per year. Based on the results of research conducted by Hafidhudin (2007), and Laela (2010) identified there are 4 (four) factors that cause inadequate management of zakat in Indonesia, namely 1) the ineffectiveness of zakat collection organizations; 2) high administrative costs for managing zakat; 3 ) information about the importance of paying zakat which is not effective; and 4) distrust of the muzakki (zakat payers) towards the zakat management organization (OPZ).

Not to mention the existence of the industrial revolution 4.0, an era marked by human, data and machine connectivity in virtual form, also known as cyber physical. The development of the industrial revolution brought about a very rapid change with the noble aim of creating a better quality of life. In the industrial era 4.0 there is a shift in innovation trends towards digital technology.

In the era of the industrial revolution 4.0 enables automation in all fields to achieve effective and efficient productivity. The application of digital supply chain information systems to all work units will minimize the role of humans as operators. In general, in the industrial era 4.0, the role of human labor changed from the role of the operator to an expert with high competence. This challenge encourages reorganization and innovation through the implementation of total quality management to increase the receipt of zakat nationally

Then adequate human resources are needed in the management of zakat and the government issues Statement of Financial Accounting Standards (PSAK) No. 109 concerning Accounting for Zakat and Charity / Alms. The existence of PSAK on zakat and infaq or alms accounting in the hope that zakat management can be openly. This means that zakat management is transparent so that the public or public can easily find out. Through the implementation of total quality management and transparency, it will facilitate the application of good governance

Based on the above background, the formulation of the problem is made by the effect of the implementation of total quality management and the application of good governance to the trust of Muzakki (Study of the Amil Zakat Institution in Batam City)

\section{LITERATURE REVIEW}

\section{Total Quality Management}

Total quality management (TQM) is a recent breakthrough in the field of management whose activities are aimed at optimizing customer satisfaction through continuous process improvement. Cascio (1995 18) argues that "TQM, a philosophy of management that is driven by the constant attainment of customer satisfaction through the continuous improvement of all organizational process".

Tenner and Detoro (1993 32) in fadilah (2011), TQM has three basic philosophies that can be drawn as a meeting 
point of various opinions about TQM, as follows

1. Focusing on customer satisfaction (Customer Focus)

Internal customers are the following workers or the following departments involved in the production / service creation process. External customers are people or organizations who buy and use company products or services. Furthermore Tenner and Detoro (1993 5193) in Fadilah (2011) revealed that the formation of a focus on customers includes three main activities, namely a. Identifying customers. b. Understand or fulfill customer expectations (understanding customer expectation). c. A mechanism for hearing customer's voice is available $b$. Understand or fulfill customer expectations (understanding customer expectation). c. A mechanism for hearing customer's voice is available (explains how to listen to the voice of the customer trough an array of readily available mechanisms or mechanisms for understanding customer).

2. Employee Empowerment and Invoivement In intense competition, employees are required to have high expertise and knowledge in carrying out their duties. For this reason, companies must provide more training and opportunities to be involved in the taking process. According to Tenner and Detoro (1993 179-182), apart from the three dimensions in building employee empowerment, namely a. Building alignment, b. Build capability with the target at $\mathrm{c}$. Building trust, can be achieved by mutual trust between managers and employees (the can trust their managers, and their managers trust them).

\section{Continuous improvement in quality}

In its implementation the process improvement is carried out based on the
Deming wheel namely plan, do, check and action (PDCA cycle) which rotates the wheels continuously to prevent the repetition of damage. The cycle is broken down into six interrelated activities (Tenner and Detoro, 1993 110-121), namely: 1. Define the problem. 2. Identify and document the process. 3 . Measuring performance. 4. Understand about various problems / why, namely by distinguishing ordinary cases, special cases, and the ability to analyze them. 5 . Develop and test ideas. 6. Evaluation and implementation of problem solving.

Then, the implementation of total quality management at LAZ, in order to create a credible zakat institution, one of the efforts that must be made is by implementing TQM. In the application of TQM, customers must be clearly defined (Mulyadi, 1996 10) ie what is meant by customers is muzzaki and mustahik. Specifically LAZ, efforts to continuously improve quality can be achieved in two ways (Budi, 2002 16), namely as follows:

1. LAZ can make a more strategic position in terms of ZIS management by disseminating more suitable conceptions of fiqh.

2. LAZ can improve results that are free from damage in the sense that it can hinder the operation of the institution.

\section{Corporate Governance}

According to the OECD in Siswanto and Aldridge (2005 2) defining corporate governance is a system used to direct and control the company's business activities. Corporate governance regulates the distribution of duties, rights and obligations of those with an interest in the life of the company, including shareholders, the board of directors, managers and all members of non-shareholder stakeholders. 
The aim of good corporate governance as stated in the OECD (1999 34) is to aim, (1) to reduce the gap between parties who have an interest in a company, (2) increase the confidence of investors in investing, (3) reduce capital costs, (4) convincing all parties of the legal commitment in managing the company and (5) creating value for the company including the relationship between stakeholders. Furthermore, in order to implement good governance, it is necessary to have standards or principles that serve as guidelines in the practice of company management to increase the value and sustainability of the company. The Organization for Economic Cooperation and Development OECD, 1999 25) has developed the following principles (a) Fairness, (b) Transparency, Accountability, and (d) Responsibility.

The unit of analysis of this research is BAZNAS Batam City. BAZNAS is a public sector organization whose main activity is to carry out an intermediary role in the management of ZIS funds, so the principles of good governance used in this study are based on the decision of the Minister of State Enterprises No. 117 / M-MBU / 2002, that in the application of good corporate governance in BUMN there are five main principles. The five principles are (a) responsibility, (b) accountability, (c) fairness, (d) transparency

\section{Tranparancy}

Transparency can be interpreted as information disclosure, both in the decision making process and in disclosing material and relevant information about the entity. The essence of the principle of transparency is to increase the disclosure (disclosure) of the performance of the entity in an orderly and timely manner (timly basis) and true (acurate) (Tangkilisan, 2003 100).

2. Accountability

Which establishes clear responsibilities of each component of the organization in line with the entity's vision, mission, goals and strategies. Each component of the organization has competencies according to their respective responsibilities (Sutedi, 2011 88). Accountability is the clarity of functions, structures, systems and accountability of the organ organs so that organizational management is carried out effectively.

\section{Responsibility}

The company has the responsibility to comply with applicable laws and regulations or regulations, including the response to the environment in which the entity is located (Tangkilisan, 2003 100). Organizational responsibility is conformity (complying) with the principles of a healthy corporation and applicable regulations. The regulations that apply here include those relating to tax matters, industrial relations, environmental protection, occupational health or safety, payroll standards and competitive.

\section{Independency}

Independence is an important principle in the implementation of Good Corporate Governance (GCG). Independence or independence is a situation where the company is managed professionally without conflict of interest and influence or pressure from any party that conflicts with applicable laws and regulations and sound corporate principles (Tangkilisan, 2003 100).

\section{Fairness}

Fairness is fairness and equality in fulfilling the rights of stakeholders arising based on agreements and applicable laws and regulations. Simply put, the reasonableness in fulfilling stakeholder rights arises based on agreements and applicable laws and regulations. Fairness is expected to make all company assets managed properly and 
prudently, so that fair and fair protection of the interests of shareholders emerges (Tangkilisan, 2003 100).

\section{Trust}

In the context of relationship marketing, trust is one dimension to determine how far a party feels the integrity and promises offered by other parties. Trust is defined as the willingness to rely on the ability, integrity and motivation of other parties to act in order to satisfy one's needs and interests as mutually and explicitly agreed upon. (Sheth and Mittal, 2004 in Tjiptono and Diana, 2003 415).

According to Anoraga (2004 228), "Trust is a descriptive idea held by someone about something". Therefore, to make a consumer feel confident about the product offered, it is inseparable from studying the consumer's behavior. Consumer behavior to be sure or believe in the insurance is greatly influenced by factors in capturing the message given to these customers. Therefore the information provided must be able to touch and provide a perception for consumers to feel confident and safe in obtaining and being offered customers in accordance with what they need. Because perception is the process of selecting, organizing and interpreting the inputs of the information provided, so as to create a meaningful picture that is captured by consumers and ultimately becomes the belief for these consumers to choose and use

According to Barnes (2003 149), some important elements of trust are;

1. Trust is the development of past experiences and actions.
2. The character expected from partners, as trustworthy and reliable.

3. Trust involves a willingness to put yourself at risk.

4. Trust involves feeling safe and confident in a partner.

From a marketing standpoint, this states that the development of trust, especially confidence, should be a fundamental component of marketing strategies aimed at leading to the creation of true customer relationships. The customer must be able to feel that he can feel that he can rely on the company. However, building trust takes a long time and only develops after repeated meetings with customers. More importantly, trust develops after an individual takes risks in dealing with his partner.

Bloemer and Poiesz (2002 68) in Widiana (2004) stated that company image influences customer satisfaction, customer satisfaction influences trust and trust influences customer commitment. Customer commitment has a strong influence on purchase intentions, price intensity and word of mouth (WOM).

Referring to the theory put forward by Garbarino and Johnson (1999 73) in Inscription, Chaniago and Sutarso (2003 129) also agree. The expectations of zakat customers or payers are a reference to service performance standards, and are often formulated based on customer beliefs or beliefs about what will happen. Customer expectations stem from controlled marketing factors such as

1. Customer requirements.

2. Word of mouth communication.

3. Offers from competitors.

\section{Hypothesis}

\begin{tabular}{lll} 
Hypothesis 1 & $:$ & Implementasi Total quality management has a significant positive effect on Musakki's trust. \\
\hline Hypothesis 2 & $:$ & The application of good governance has a significant positive effect on Musakki's trust \\
\hline Hypothesis 3 & $:$ & $\begin{array}{l}\text { Total quality management and the implementation of good governance simultaneously have } \\
\text { a significant positive effect on Musakki's trust }\end{array}$ \\
\hline
\end{tabular}




\section{Framework for thinking}

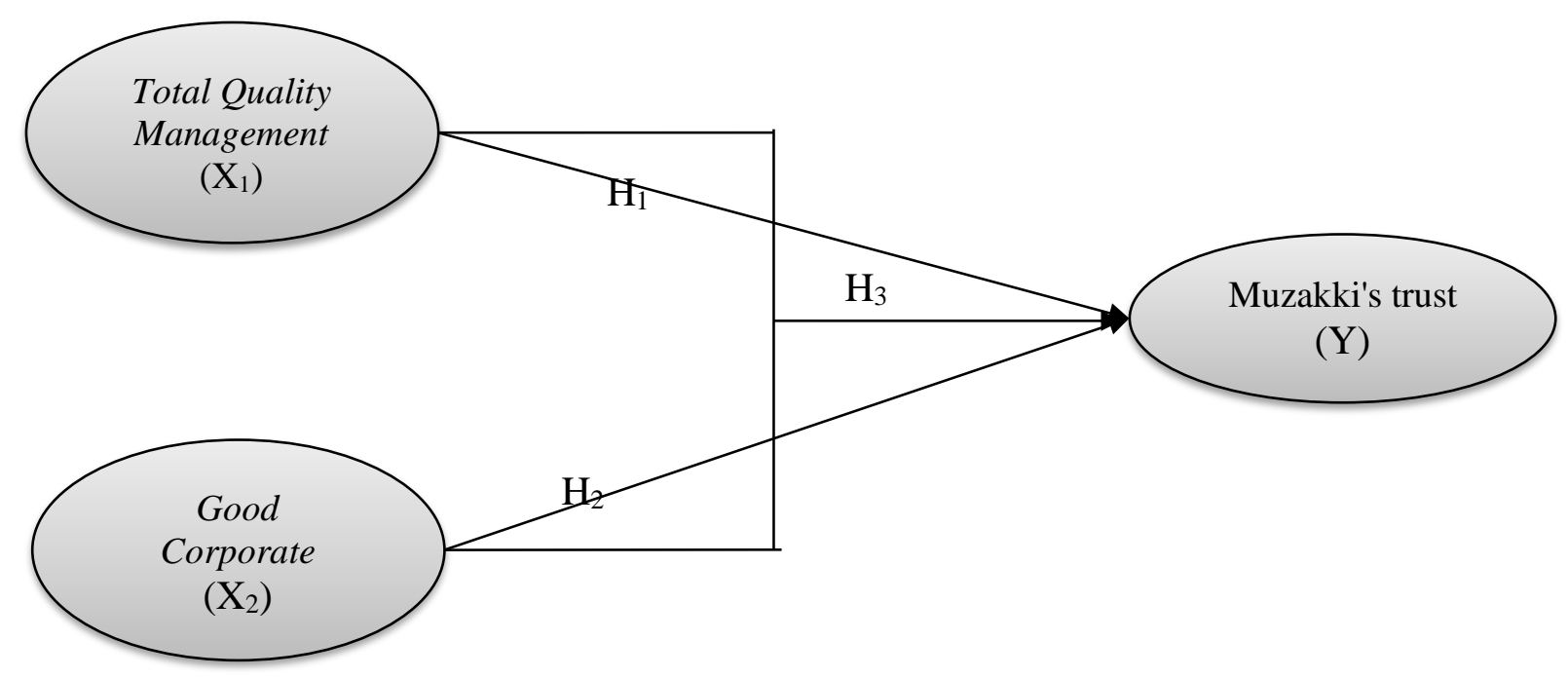

Figure 1. Framework for thinking

\section{RESEARCH METHOD}

\section{The Research Design}

The research design is quantitative with a hypothesis that aims to test the effect of the implementation of Total quality management and the application of good governance to Musakki's trust. Both factors are thought to have an influence on Musakki's beliefs.

\section{Population, Samples and Sampling Techniques}

The population in the obligatory zakat in Batam City as of December 2017 The sample is part of the number and characteristics possessed by that population. Based on Hair, et al (2010) the use of the number of samples is calculated based on the number of indicators in each independent variable and the dependent variable used multiplied by 5 10. This study uses 20 indicators, so the number of samples used in this study is $20 \mathrm{x}$ $5=100$ (one hundred) samples.

The sampling technique in this study was done by convenience sampling, which is done by taking samples from the population. In this sampling design information is obtained from elements of the population who are willing to provide that information. Each member of the population is called an element. Element is the person or object of the information sought (Hair, 2010).

\section{Data Analysis Technique}

\section{Validity dan Reliability Test}

1) Validity Test

Validity comes from the word validity which means the extent to which the accuracy and accuracy of a measuring instrument in carrying out its measurement function. Valid means that the instrument can be used to measure what is being measured I". How to measure content validity using internal consistency, namely the Pearson product correlation method. If the results of the probability between each statement with the results of the total score indicates the results of $r$ count greater than from $r$ table then the statement is said to be valid. 
2) Reliability test

The reliability test is used to determine the extent to which the measurement results remain consistent when measured twice or more for the same symptoms using the same measuring instrument. A questionnaire is said to be reliable or reliable if a person's answer to a question is consistent or stable from time to time. The reliability test in this study was carried out with the Cronbach Alpha test. A construct or variable is said to be reliable if it gives a Cronbach Alpha value> 0.60 .

According to Ghozali (2006 110), before the data is processed a classic assumption test consists of
a. Normality Test
b. Multicollinearity
c. Heteroscedasticity

\section{Multiple Linear Regression Test}

Research equation model is as follows

$$
Y=\alpha+\beta_{1} X_{1}+\beta_{2} X_{2}+e
$$

\section{Remarks}

$$
\begin{array}{ll}
\mathrm{Y} & : \text { muzakki trust } \\
\alpha & : \text { Constants } \\
\beta & : \text { Regression Coefficient } \\
\mathrm{X}_{1} & : \text { total quality management } \\
\mathrm{X} 2 & : \text { good governance } \\
\mathrm{e} & : \text { Error }
\end{array}
$$

\section{Hypothesis Test}

Hypothesis testing is done using multiple linear regression, namely $\mathrm{F}$ test and $\mathrm{t}$ test with the help of SPSS software version 23.00

\section{ANALYSIS AND DISCUSSION}

\section{Description of Research Object}

Riau Province has 2 cities and 5 regencies, and there are 70 districts, 145 villages and
275 villages with a total occupation of $1,873,274$ inhabitants. While the city of Batam has 12 districts and 64 villages (out of a total of 70 districts, 141 villages and 275 villages throughout the Riau Islands). In 2017, the population was $1,062,250$ people with an area of $960.25 \mathrm{~km}^{2}$ and a population of 1,106 inhabitants $/ \mathrm{km}^{2}$. In this section the researcher will classify respondents on the basis of characteristics or profiles, especially the work of the respondent. The following is the respondent's work presented in the table below.

Table 1. Frequency and Percentage of Respondents' Work

\begin{tabular}{cccc}
\hline No & $\begin{array}{c}\text { Work of The } \\
\text { Respondent }\end{array}$ & Amount & Prosentase \\
\hline $\mathbf{1}$ & Civil servants & 54 & $54,0 \%$ \\
\hline $\mathbf{2}$ & $\begin{array}{c}\text { Private } \\
\text { employees }\end{array}$ & 34 & $31,0 \%$ \\
\hline $\mathbf{3}$ & TNI, Polri & 15 & $5,0 \%$ \\
\hline & Total Amount & 100 & $100 \%$ \\
\hline
\end{tabular}

Based on table 1 above, out of 100 respondents there were 54 respondents or $54.0 \%$ were civil servants, 34 respondents or $34.0 \%$ were private employees and the last 15 respondents or $15.0 \%$ were members of the TNI and Polri.

\section{Validity and Reliability Test}

\section{Validity test}

Validity test is done by looking at the significance of the correlation between item scores and total item scores where a statement item will be said to be valid if the correlation between the statement item scores with the total item scores of the statement has a significant correlation less than 0.05 ( Ghozali, 2009 49). R table value is obtained by the formula $\mathrm{df}=\mathrm{n}-2$ with a significant level of 5\%. The number of samples in this study were 100 respondents. 
Table 3. Test the Validity of Total Quality Management (X1), Implementation of Good Governance (X2) and Muzakki Trust (Y1)

\begin{tabular}{|c|c|c|c|c|c|c|c|}
\hline Instrument & $\mathbf{r}$ table & $r$ count & Remark & Instrument & r table & $\mathbf{r}$ count & Remark \\
\hline \multicolumn{4}{|c|}{ Total quality management $\left(X_{I}\right)$} & \multicolumn{4}{|c|}{ Total quality management $\left(X_{I}\right)$} \\
\hline $\mathrm{X}_{1.1}$ & 0,197 & 0,808 & Valid & $\mathrm{X}_{1.6}$ & 0,197 & 0,805 & Valid \\
\hline $\mathrm{X}_{1.2}$ & 0,197 & 0,898 & Valid & $\mathrm{X}_{1.7}$ & 0,197 & 0,797 & Valid \\
\hline $\mathrm{X}_{1.3}$ & 0,197 & 0,771 & Valid & $\mathrm{X}_{1.8}$ & 0,197 & 0,755 & Valid \\
\hline $\mathrm{X}_{1.4}$ & 0,197 & 0,800 & Valid & $\mathrm{X}_{1.9}$ & 0,197 & 0,898 & Valid \\
\hline $\mathrm{X}_{1.5}$ & 0,197 & 0,898 & Valid & $\mathrm{X}_{1.10}$ & 0,197 & 0,799 & Valid \\
\hline \multicolumn{4}{|c|}{ Good governance $\left(\mathrm{X}_{2}\right)$} & \multicolumn{4}{|c|}{ Muzakki Trust $\left(Y_{1}\right)$} \\
\hline $\mathrm{X}_{2.1}$ & 0,197 & 0,229 & Valid & $\mathrm{Y}_{1.1}$ & 0,197 & 0,603 & Valid \\
\hline $\mathrm{X}_{2.2}$ & 0,197 & 0,898 & Valid & $\mathrm{Y}_{1.2}$ & 0,197 & 0,731 & Valid \\
\hline $\mathrm{X}_{2.3}$ & 0,197 & 0,904 & Valid & $Y_{1.3}$ & 0,197 & 0,765 & Valid \\
\hline $\mathrm{X}_{2.4}$ & 0,197 & 0,887 & Valid & $\mathrm{Y}_{1.4}$ & 0,197 & 0,848 & Valid \\
\hline $\mathrm{X}_{2.5}$ & 0,197 & 0,745 & Valid & $\mathrm{Y}_{1.5}$ & 0,197 & 0,808 & Valid \\
\hline
\end{tabular}

It is known that the value of $r$ table for a sample of 100 at a significant level of 0.05 is 0.197. Pearson correlation value ( $\mathrm{r}$ arithmetic) obtained from ten question items on the total quality management variable is greater than the value of $r$ table, then all the question items are declared valid. While the Pearson correlation value ( $\mathrm{r}$ arithmetic) obtained from the five item questions on the variable implementation of good governance is greater than the value of $r$ table, then all items in question are declared valid. On the Pearson correlation value ( $\mathrm{r}$ count) obtained from five question items on the muzaki trust variable is greater than the value of $r$ table, then all the question items are declared valid. Then it can be concluded that the total quality management variable, the application of good governance and muzaki trust are valid.

Reliability test

The reliability test is done by calculating the Cronbach alpha of each item in a variable. The instrument used in the variable is said to be reliable or reliable if it has a Cronbach alpha of more than 0.60 (Sekaran, 2000 204). Cronbach alpha value of this research instrument is 0.947 for the variable total quality management (X1), 0.799 for the variable implementation of good governance (X2), and 0.804 for muzakki trust (Y). From the Cronbach alpha figures it can be concluded that the instruments used in this study are reliable. The reliability test results for each variable are listed in Table 4. below.

Table 4. Total Quality Management Variable Reliability (X1), Implementation of Good Governance (X2) and Muzakki Trust (Y1)

\begin{tabular}{lccl}
\hline \multicolumn{1}{c}{ Variabel } & $\begin{array}{c}\text { Coefficient } \\
\text { Alpha }\end{array}$ & $\begin{array}{c}\text { Alpha } \\
\text { Cronbach }\end{array}$ & Remark \\
\hline Total Quality Management $\left(\mathrm{X}_{1}\right)$ & 0,947 & 0,600 & Reliabel \\
\hline Good Governance $\left(\mathrm{X}_{2}\right)$ & 0,799 & 0,600 & Reliabel \\
\hline Muzakki Trust $(\mathrm{Y})$ & 0,805 & 0,600 & Reliabel \\
\hline
\end{tabular}


a. Classical Assumptions Testing Classical Assumptions Testing to find out whether the data used are free from problems of normality, multicollinearity, and heteroscedasticity. If the classical assumptions are not met, it will cause a bias in the results of the research. The first assumption regarding the presence or absence of Multicollinearity between independent variables. The method used in this study is the pair correlation method between variables. Testing is done with SPSS 23 for windows.
Normality test aims to test whether in the regression model, residuals have a normal distribution (Ghozali, 2013). In this study using the Lilliefors Normality Test (Kolmogrov-Smirnov) contained in the SPSS procedure (Uyanto, 2009 39). If the points on the normal probability plot are collected around a straight line, then the regression model residuals are normally distributed. Residual normality test results with a normal probability plot. Here are the results of the normality test.

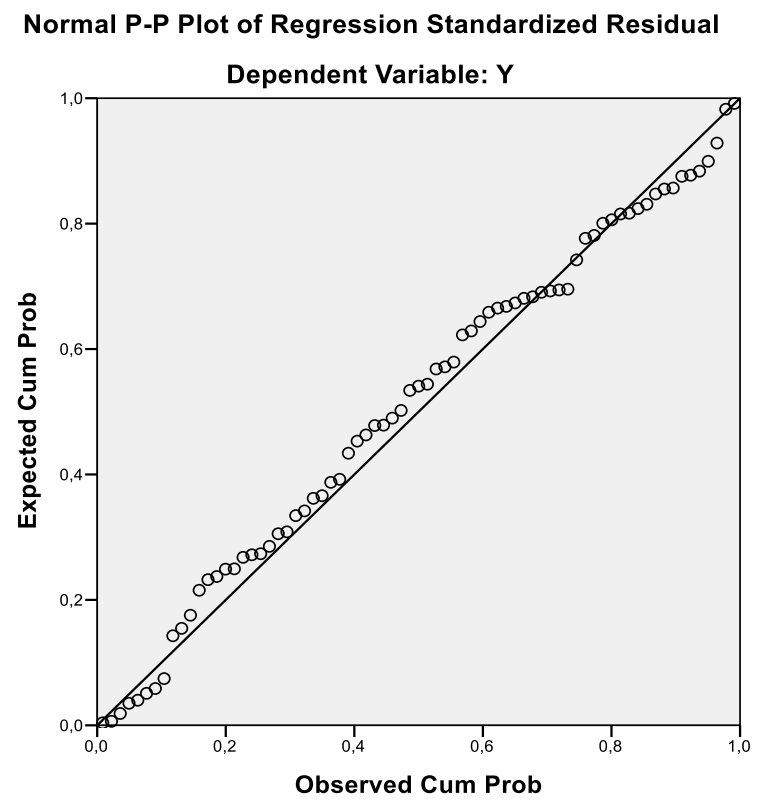

Figure 2. Normality test

b. Multicollinearity Test

The results of this test get a VIF value $=$ 1,000 indicating that there are no symptoms of multicollinearity because the VIF value $<10$. The simplified diagnosis of multicollinearity in the multiple regression model is by looking at the Variance Inflation Factor or VIF value, that one data ultololinierity occurs when the VIF value is greater than 1 and smaller than 10 .

Tabel 5. Value Variance Inflation Factor

\begin{tabular}{cccc}
\hline \multirow{2}{*}{ No } & \multirow{2}{*}{ Variable } & \multicolumn{2}{c}{ Collinearity Statistics } \\
\cline { 3 - 4 } & & Tolerance & VIF Value \\
\hline 1 & Total Quality Management $\left(\mathrm{X}_{1}\right)$ &, 179 & 5,592 \\
\hline 2 & Good Governance $\left(\mathrm{X}_{2}\right)$ &, 179 & 5,592 \\
\hline
\end{tabular}


The test results show that there are no symptoms of multicollinearity because the VIF value is greater than one and smaller 10 .

\section{c. Heteroscedasticity Test}

Heteroscedasticity test is done through scatterplot graph analysis. If a scatterplot graph has a data distribution pattern that forms a certain pattern, then it shows homoskedastic. Conversely, if the scatterplot chart pattern does not form a particular pattern or randomly, then it does not show heteroscedasticity. The random pattern in the graph as shown in the figure below shows the linear regression model does not meet heteroscedastic assumptions.

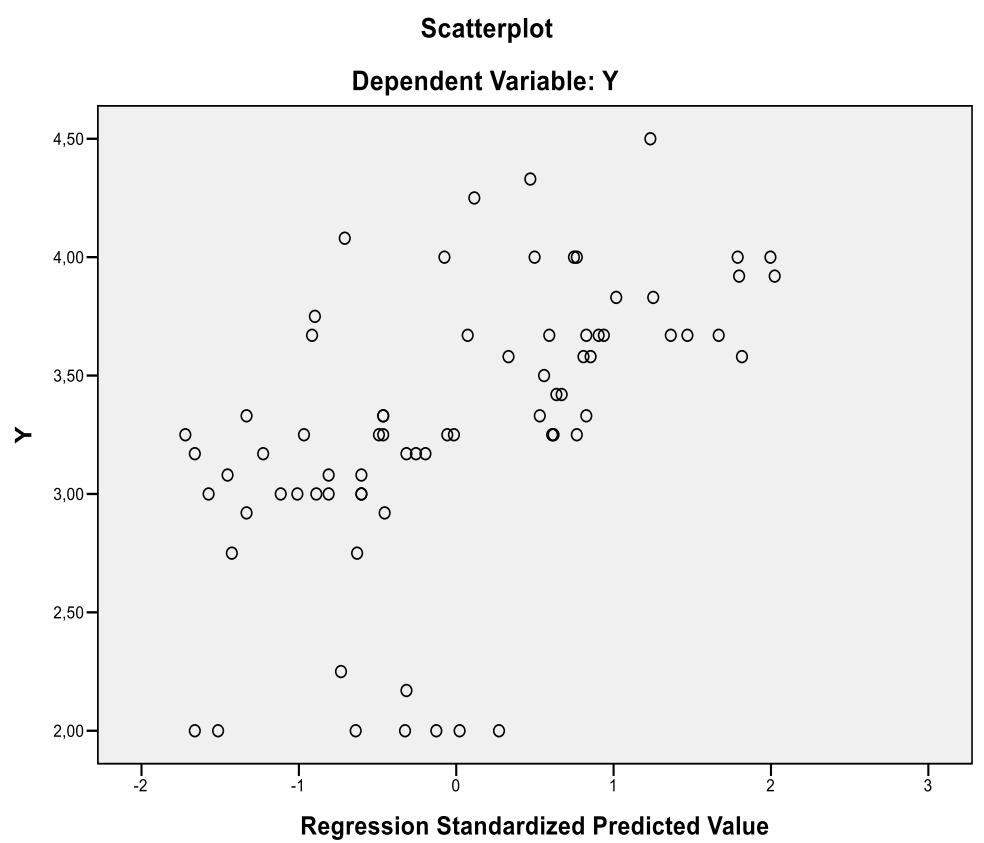

Figure 2. Heteroscedasticity test

\section{Hypothesis Testing}

Hypothesis testing is done to provide answers to research problems that have been prepared previously. Hypothesis testing in this study uses multiple regression using the SPSS 23 for windows program. Hypothesis testing includes a. F Test

The $\mathrm{F}$ test is used to find out whether the regression model can be used to test the effect of Total quality management and the simultaneous application of good governance to the trust of Musakki (Y). The detailed results of the $F$ test can be seen in the following table.

Tabel 6. F test

\begin{tabular}{llccl}
\hline Model & Sum of Squares & Df & F & Sig. \\
\hline 1 Regression & 15,730 & 2 & 51,641 & $.000^{*}$ \\
Residual & 14,773 & 97 & & \\
Total & 30,502 & 99 & & \\
\hline
\end{tabular}


Based on table 6 shows that known significant values of the two independent variables (Total quality management and the implementation of good governance) simultaneously on Musaki's trust. equal to 0,000 , meaning less than 0.05 . So $\mathrm{HO}$ is rejected and $\mathrm{H} 1$ is accepted, which means the regression model matches the data. b. T Test

To determine the effect of the independent variable and the dependent variable used multiple linear regression analysis. The results of multiple linear regression tests using the SPSS 23 for Windows application program are obtained as shown in table 7

Table 7. Multiple Regression Analysis

\begin{tabular}{|c|c|c|c|c|c|c|}
\hline & \multirow[t]{2}{*}{ Model } & \multicolumn{2}{|c|}{$\begin{array}{c}\text { Unstandardized } \\
\text { Coefficients }\end{array}$} & \multirow{2}{*}{$\begin{array}{c}\begin{array}{c}\text { Standardized } \\
\text { Coefficients }\end{array} \\
\text { Beta } \\
\end{array}$} & \multirow[t]{2}{*}{$\mathbf{t}$} & \multirow[t]{2}{*}{ Sig. } \\
\hline & & $\mathbf{B}$ & Std. Error & & & \\
\hline \multirow[t]{3}{*}{1} & (Constant) & 1,750 & ,296 & & 5,910 & 000 \\
\hline & Total Quality Management $\left(\mathrm{X}_{1}\right)$ & ,986 &, 154 & 1,070 & 6,403 & ,000 \\
\hline & Good governance $\left(\mathrm{X}_{2}\right)$ &,- 454 & ,184 &,- 412 & $-2,465$ & ,015 \\
\hline
\end{tabular}

Based on Table 7 it is obtained that the multiple linear regression equation is as follows

$$
Y=1,750+0,986 X 1-0,454 X 2+e
$$

From this equation, it can be explained as follows:

1. A constant value $(\alpha)$ of 1,750 means that if the total quality management and implementation of good governance are zero then Musaki's trust. (Y) is 1,750 .

2. Regression coefficient $(\beta)$ for Total quality management and the application of good governance means that if there is an increase in Total quality management and the application of good governance there will be an increase in Musaki's trust. (Y) of 1,750 .

Table 8. Multiple Linear Regression for Total quality management and muzakki's trust (Y)

\begin{tabular}{|c|c|c|c|c|c|c|}
\hline & \multirow{2}{*}{ Model } & \multicolumn{2}{|c|}{ Unstandardized Coefficients } & \multirow{2}{*}{$\begin{array}{c}\begin{array}{c}\text { Standardized } \\
\text { Coefficients }\end{array} \\
\text { Beta } \\
\end{array}$} & \multirow[t]{2}{*}{$\mathbf{t}$} & \multirow[t]{2}{*}{ Sig. } \\
\hline & & B & Std. Error & & & \\
\hline \multirow[t]{2}{*}{1} & (Constant) & 1,750 & ,296 & & 5,910 & 000 \\
\hline & Total quality management $\left(\mathrm{X}_{1}\right)$ & ,986 &, 154 & 1,070 & 6,403 & ,000 \\
\hline
\end{tabular}

Based on table 8, it was found that the significant value of total quality management was 0,000 (lu003c0.05). It can be concluded that $\mathrm{H} 0$ is rejected and $\mathrm{H} 1$ is accepted, so it can be interpreted that
Total quality management influences the belief in music. (2) The effect of applying good governance to the belief in muzaki (Y) 
Tabel 9. Multiple Linear Regression for good governance and muzakki Belief (Y)

\begin{tabular}{|c|l|r|r|r|r|r|}
\hline \multirow{2}{*}{\multicolumn{2}{|c|}{ Model }} & \multicolumn{2}{c|}{$\begin{array}{c}\text { Unstandardized } \\
\text { Coefficients }\end{array}$} & \multicolumn{1}{c|}{$\begin{array}{c}\text { Standardized } \\
\text { Coefficients }\end{array}$} & \multicolumn{1}{c|}{ t } & \multicolumn{1}{c|}{ Sig. } \\
\cline { 2 - 7 } & B & Std. Error & Beta & & \\
\hline 1 & (Constant) & 1,750 &, 296 & & 5,910 &, 000 \\
\hline & Good governain $\left(\mathrm{X}_{2}\right)$ &,- 454 &, 184 &,- 412 & $-2,465$ &, 015 \\
\hline
\end{tabular}

Based on table 9, it was found that the significant value of the application of good governance was 0.015 ( (u003c0.05). It can be concluded that $\mathrm{H} 0$ is rejected and $\mathrm{H} 1$ is accepted, so it can be interpreted that the implementation of good governance affects the trust of muzaki

\section{Discussion}

The discussion of each variable is as follows;

a. Total quality management has a significant positive effect on muzaki trust

Based on the results of the study found that total quality management has a partial effect on muzaki trust, this can be seen from the significance value of 0,000 $<0.05$, then Ho is rejected at the level of significance, then $\mathrm{Ho}$ is rejected at a significance level of $5 \%$ so it can be concluded that total quality management has a positive and significant influence on muzaki's trust indicated by a regression coefficient of 0.986 . This means that the more total quality management the total quality management will increase, it will significantly increase the trust of muzaki. Based on these results $\mathrm{H} 2$ who suspected total quality management had an influence on muzaki trust

b. The implementation of good governance has a significant positive effect on muzaki trust

Based on the results of the study found that the application of good governance has a partial influence on muzaki trust, this can be seen from the significance value of $0.015 \mathrm{lu} 003 \mathrm{c} 0.05$, then Ho is rejected at the $5 \%$ significance level so it can be concluded that the application of good governance has a negative and significant effect on muzaki trust indicated by a regression coefficient of -0.454 . This means the more the application of good governance increases, it will significantly reduce the trust in muzaki. Based on these results $\mathrm{H} 2$ who suspected the application of good governance had an influence on muzaki trust was acceptable.

\section{CONCLUSIONS AND SUGGESTIONS}

\section{Conclusions}

1. Total quality management has a significant positive effect on muzakki's trust.

2. The application of good governance has a significant negative effect on muzakki trust

3. Total quality management and the implementation of good governance simultaneously have a significant positive effect on muzakki's trust

\section{Suggestions}

Suggestions to be followed up as a matter of consideration for the management of the Amil Zakat Institution in Batam who will conduct socialization on zakat to the public in a transparent manner and all the questions are open and easily accessed. 


\section{REFERENCES}

Fadilah, Sri. 2011. The Effect of Implementation of Internal Control and Total Quality Management on the Implementation of Good Governance (Study on Amil Zakat Institutions throughout Indonesia). Aceh XIV National Symposium.

Anoraga, Pandji. 2004. Business Management. Jakarta Rineka Cipta.

Adib Machrus et al. 2013. The organization's Guide to Maintainer Zakat. Directorate General of the Islamic Community Guidance. The Directorate Of Enforcement Of Zakat.

Budi Budiman, 2002, Potential of ZIS Funds as Islamic Economic Instruments of Management Theory and Implementation. Paper presented at the National Symposium on the National System of Islamic Economics, Yogyakarta.

Fandy Tjiptono and Anastasia Diana.2001. Total Quality Management. Revised Edition. ANDI Publisher. Yogyakarta.

Hafidhuddin, Didin. 2007. In order to Gain blessings and Treasures (movement to cultivate the religious obligatory, Infaq, Alms, Endowments), Jakarta Gema Insani.

Hair, J. F., Black. W. C., Babin. B. J.; and Anderson. R. E. 2010, Multivariate Data Analysis, 7th ed. Pearson Prentice Hall, New Jersey

https://id.wikipedia.org/wiki/DList_kecamat an_dan_kelurahan_di_Kota_Batam, accessed September 10, 2019.

Mulyadi, 1992, Management Accounting Concepts, Benefits and Engineering, 1st Edition, STIE-YKPN Publisher Section, Yogyakarta.
Mulyadi, Yogyakarta 1996, Total Quality Management Paradigm Shift in Corporate Management, Journal of Accounting and Management, February 1996 Edition, Yogyakarta, STIE - YKPN.

Samdin, 2002. Zakat Motivation on Institutional Benefits and Role Study. Paper presented at the National Symposium on Islamic Economics, Yogyakarta.

Tenner, Arthur R and Detoro Irving J. 1993. Total Quality Management. AdisonWesley publishing company. The USA.

Fadilah, Sri. 2011. The Effect of Implementation of Internal Control and Total Quality Management on the Implementation of Good Governance (Study on Amil Zakat Institutions throughout Indonesia). XIV Aceh National Symposium on $\wedge \wedge$

Tangkilisan, Hessel. 2003. The implementation of public policy. Yogyakarta: Lukman Offset.

Prasasti, RD, Chaniago, H., and Sutarso, Y., 2003, Effect of Relationship Marketing on Customer Satisfaction in the Life Insurance Services Industry, Venture Journal Vol.6, No.2, August 127-145.

Widiana, M., E., 2004, The Impact of Relational Marketing Factors in Forming Customer Loyalty in the Insurance Business, Airlangga University Economic Magazine XIV Year, December 3, Surabaya.

Cahyo Budi Santoso

Universitas Riau Kepulauan, Batam

Ahmad Gamal

Universitas WR Supratman, Surabaya 